\title{
Risk Communication in Public Health Practices and Coronavirus Disease 2019 (COVID -19): Social Media Analysis of Health Authorities
}

\section{Halk Sağlığı Uygulamalarında Risk iletişimi ve Koronavirüs Hastalığı 2019 (COVID -19): Sağlık Otoritelerinin Sosyal Medya Analizi}

(D) Miraç Nevzat KARAKOÇ1, id Hüseyin KOÇAK², id Cüneyt ÇALIŞKAN², id Kerem KINIK³

${ }^{1}$ Çanakkale City Administrations, Investment and Construction Directorate, Çanakkale, Turkey

${ }^{2}$ Çanakkale Onsekiz Mart University, Emergency Aid and Disaster Management Department, Çanakkale, Turkey

3University of Health Science, Management and Organization Department, İstanbul, Turkey

\section{ABSTRACT}

Objective: This study aims to evaluate information on the website of the Ministry of Health about the COVID-19 pandemic, the social media accounts of health authorities, and the COVID-19 cases.

Methods: In this descriptive ecological research, the content analysis of the posts about COVID-19, which were shared for health professionals and the public on the official website of the Ministry of Health, was conducted. The content traffic of the social media accounts of the health authorities about the pandemic and the daily number of cases along with recovery and death rates related to the pandemic were analyzed.

Results: The first COVID-19 post was sent on 22 January 2020 through the official Twitter account of the Minister of Health. After the first tweet about COVID-19, the first positive case was seen in the $50^{\text {th }}$ day, while the first death was seen in the $57^{\text {th }}$ day and the first recovery case was seen in the $67^{\text {th }}$ day. There is a significant positive correlation between the number of days passed and the number of cases, deaths, recoveries, comments, retweets and likes that the tweets of the Minister received; between the number of cases and the number of deaths and recovery cases; between fatal cases and recovery cases.

\section{ÖZ}

Amaç: Bu çalışma coronavirus hastalığı (COVİD-19) pandemisine karşı T.C. Sağlık Bakanlığı’nın web sitesinde yer alan bilgilerin ve sağlık otoritelerinin sosyal medya hesapları ve görülen olguların değerlendirilmesini amaçlamaktadır.

Yöntemler: Tanımlayıcı ekolojik tipteki araştırmada T.C. Sağlık Bakanlığı'nın resmi web sitesindeki COVID-19 ile ilgili halka ve sağlık personeline yönelik paylaşımların içerik analizi ve sağlık otoritelerinin sosyal medya hesaplarındaki (twitter) salgınla ilgili trafiklerinin ve hastalığa ait günlük olgu, iyileşme ve ölüm sayıları analiz edilmiştir.

Bulgular: İlk COVID-19 paylaşımı 22 Ocak 2020 tarihinde Sağlık Bakanı'nın resmi twitter hesabı üzerinden yapılmıştır. COVİD-19 hakkında atılan ilk tweettin 50. gününde ilk pozitif olgu, 57. gününde ilk ölüm ve 67 . gününde ilk iyileşen olgular görülmüştür. Geçen gün sayısı ile olgu, ölüm, iyileşen ve bakan tweetinin aldığı beğenmeler arasında; olgu ve ölüm sayıları arasında; ölüm ve iyileşen olgular arasında kayda değer pozitif korelasyon vardır.

Sonuç: Sağlık otoritelerinin tweeter hesaplarına ait tweet trafiği ile COVİD-19 olguları, ölüm, iyileşme ve gün arasında bir korelasyon ilişkisi saptanmışır. Bu nedenle, pandemi gibi afetlerde halkın
Address for Correspondence: Miraç Nevzat KARAKOÇ, Çanakkale City Administrations, Investment and Construction Directorate, Çanakkale, Turkey

E-mail: mnkarakoc@hotmail.com ORCID ID: orcid.org/0000-0001-7135-0858

Cite this article as: Karakoç MN, Koçak H, Çalışkan C, Kınık K. Risk Communication in Public Health Practices and Coronavirus Disease 2019 (COVID -19): Social Media Analysis of Health Authorities. Bezmialem Science 2020;8(Supplement 2):41-47.
Received: 21.05 .2020

Accepted: 15.06 .2020 
Conclusion: A correlation was found between the tweet traffic of the health authorities' twitter accounts and the number of COVID-19 cases, deaths, recoveries and days passed. Therefore, social platforms can be an important risk communication tool for public health in informing and managing the community in disasters like pandemics.

Keywords: Risk communication, social media, pandemic, epidemic, COVID-19 bilgilendirilmesi ve yönetiminde sosyal platformlar halk sağlığı açısından önemli bir risk iletişim aracı olabilir.

Anahtar Sözcükler: Risk iletişimi, sosyal medya, pandemi, salgın, COVİD-19

\section{Introduction}

Pandemic is a global epidemic, and the new coronavirus type (COVID-19) is the first coronavirus pandemic known to cause an emergency. Over the past century, new influenza viruses have caused 4 known pandemics: Spanish flu (1918) (H1N1 virus), Asian flu (1957) (H2N2), Hong Kong flu (1968) (H3N2) and Swine flu (2009) (H1N1) pdm09. Since most of the research on pandemics are specific to flues, information gained from those pandemics can be adapted to COVID-19 and the new outbreak can be overcome in the mildest way (1). Accordingly, the guides prepared by countries against influenza outbreaks and their risk communication strategies for informing the public come into prominence.

Risk communication can be carried out with well-thought-out messaging and program contents developed by newer social media organizations (i.e., social networks, smartphones, instant messaging) along with traditional mass media. However, despite the improvement in communication tools, government officials generally state that people are unprepared for disasters (2). The best example of this can be seen in the process of epidemic diseases turning into pandemics as a result of society's failure to take necessary measures despite all the measures that have been taken by the states.

The Ministry of Health of Turkey published the Pandemic Influenza National Readiness Plan study in 2019 in coordination with public health units and private sector partners in order to provide an effective and coordinated response to flu epidemics (3). In this plan, how to conduct risk communication during the delivery of the instructions required to protect the public from pandemics is explained. However, since disasters do not affect everyone in the same way due to social injustice (4), it may be necessary to reach the public through different communication channels. For this reason, web-based content and social media applications that almost everyone can access today are seen as tools that can provide direct communication with the public as they have a great potential in increasing the resistance of the society against disasters (5-7). However, although social media is used as a platform where emergency alerts are shared by public health institutions, false information and rumors spread in the public are a disadvantage for public health control (8-10). In this study, it is aimed to evaluate COVID-19 cases as well as content of information about the COVID-19 pandemic on the website of the Ministry of Health and the twitter traffic of health authorities.

\section{Methods}

The website of the Ministry of Health of Turkey about COVID-19 and the official twitter accounts of the Ministry of Health, General Directorate of Public Health and the Health Minister (@saglikbakanlig, @halksagligigm and @ drfahrettinko, respectively) constitute the population of the descriptive ecological type of epidemiological study. The general introduction of the COVID-19 website of the Ministry of Health and the contents of the guides, presentations, algorithms, forms, publications, and billboard buttons, in which various tools for healthcare staff and the public were collected, were examined. Frequency distributions of daily like, comment and retweet traffic on the official twitter accounts of the Ministry of Health, General Directorate of Public Health, and the Health Minister were determined from 22.01.2020, when the COVID-19-related posts were started to be shared directly, until 17.05.2020. However, the data traffic was given started from 10.03.2020, the date when the COVID-19 pandemic was observed in Turkey for the first time (the first positive case). The time trend relationship in Turkey between 10.03.2020 and 17.05.2020 was observed: Since the official Twitter account of the Minister of Health did not contain missing data, the traffic of (1) comments, (2) retweets, (3) likes, and (4) the time that passed since the first tweet (day), COVID-19 (4) cases and (5) deaths in Turkey. The relationship between variables (day, case, death, recovered, received comments, retweets and likes for Minister's tweets) was analyzed by the Spearman rank-correlation $(\mathrm{p}<0.05)$. The analyses were carried out with SPSS 19.0 statistical software package (IBM; Armonk, New York USA).

\section{Results}

\section{Findings about the COVID-19 website}

The Ministry of Health has an online website with the extension of https://Covid19bilgi.saglik.gov.tr/tr/ to inform healthcare staff and the public. Upon entering the website, a guiding banner welcomes the user with new information about COVID-19. In the upper left corner of the website, there are links to various social network accounts belonging to the Ministry of Health and there is a search option in the upper right corner. Again, at the top right, there are tabs for decisions made for institutions, news and frequently asked questions related to COVID-19. There are various informative items under the buttons of what is COVID-19?, what are the symptoms?, how is it transmitted?, 
who are at risk?, how the diagnosis is made? and ways of protection? in the middle line of the website. There are also Daily Coronavirus table of Turkey and General Coronavirus table of Turkey in the middle line of the website. These tables are updated daily. Below them are videos with famous actors describing protective measures for COVID-19, a welcome announcement, and radio spots. At the bottom of the website, there are buttons for various documents and treatment, protective equipment usage suggestions, case inquiry guide and list of provinces to send samples for healthcare staff. Below are the contents of the buttons with various documents presented to the public and healthcare staff:

\section{COVID-19 Guidebook}

The renewed edition was published by the Ministry of Health, General Directorate of Public Health on 25 March 2020 under the name of COVID-19 (SARS-CoV2 Infection) Guidebook. The content of this guide includes information on COVID-19 under the main topics of epidemiology, sources and transmission routes, clinical features, laboratory tests, case definition and case management, sampling, storage and transportation of the sample, contact tracking, infection control and isolation, patient management and treatment, and the things that people going to a country where a case has been seen should do.

\section{COVID-19 Presentations}

There is one presentation that offers information about the general features of COVID-19 and protection measures.

\section{COVID-19 Algorithms}

There are four algorithms under the headings of the case management flow chart in $2^{\text {nd }}$ and $3^{\text {rd }}$ level health institutions; tracking algorithm for passengers and flight attendants; polyclinic / emergency patient management chart; evaluation of healthcare professionals with COVID-19 contact.

\section{COVID-19 Forms}

It contains a case information form, a follow-up form and a possible COVID-19 case inquiry guide for outpatients.

\section{COVID-19 Publications}

For public use, it contains the new coronavirus disease (COVID-19) booklet, "14 rules against the risk of new coronavirus" poster, "home monitoring (quarantine)" rule/"14Day Rules" poster, "wash your hands frequently" poster, "protect your health while traveling" poster, "how should we wash our hands" poster, "virus protection is in our hands" poster, "when and how should we wash our hands" poster, "let's wash our hands and protect our health" poster, leaflet about suggestions for our citizens returning from UMRE worship, medical mask use brochure.

For healthcare personnel, it contains a standard measures poster, contact isolation poster, droplet isolation poster, respiratory insulation poster, appropriate use of personal protective equipment poster.

\section{COVID-19 Billboard}

There are billboards prepared for COVID-19 with the titles of "virus protection is in our hands", "let's wash our hands and protect our health", "how should we wash our hands", and "coronavirus is not stronger than the measures we will take".

\section{COVID-19 Results About Twitter Posts}

The first COVID-19 post was shared on 22 January 2020 by the official twitter account of the Minister of Health, @ drfahrettinkoca. Most tweet traffic belongs to this account. It is successively followed by @saglikbakanligi and @halksagligigm in terms of the density of tweet traffic. It seems that the General Directorate of Public Health has almost no sharing of COVID-19 on its official twitter account, @halksagligigm. After the sharing of the first tweet, the first positive case was detected on the $50^{\text {th }}$ day, the first death on the $57^{\text {th }}$ day and the first recovery case on the $67^{\text {th }}$ day. A total of 149435 positive cases, 4140 deaths, and 109962 recoveries were observed on 17.05.2020, 118 days after the first tweet (Table 1 ). The daily case, death and recovery trend of COVID-19 is given in Figure 1.

There is a strong and significant and positive correlation between the number of days passed and the number of recoveries $(\mathrm{r}=0.804, \mathrm{p}<0.01)$. There is a moderate and significant and positive correlation between the number of days passed and the number of deaths $(\mathrm{r}=0.549, \mathrm{p}<0.01)$. There is a strong and significant and positive correlation between the number of COVID-19 cases and the number of deaths $(r=0.904, p<0.01)$. There is a moderate and significant positive correlation between the COVID-19 fatal cases and the number of comments that the tweets of the Minister received ( $\mathrm{r}=0.549, \mathrm{p}<0.01)$ (Table 2).

\section{Discussion}

The World Health Organization (WHO) declared a global public health emergency for COVID-19 on 20 January 2020, and today the number of positive cases has globally exceeded two million (11). Before the declaration of the pandemic by WHO, Turkey began to take some early measures by placing thermal cameras at the international airports. One of these measures is the effective management of risk communication

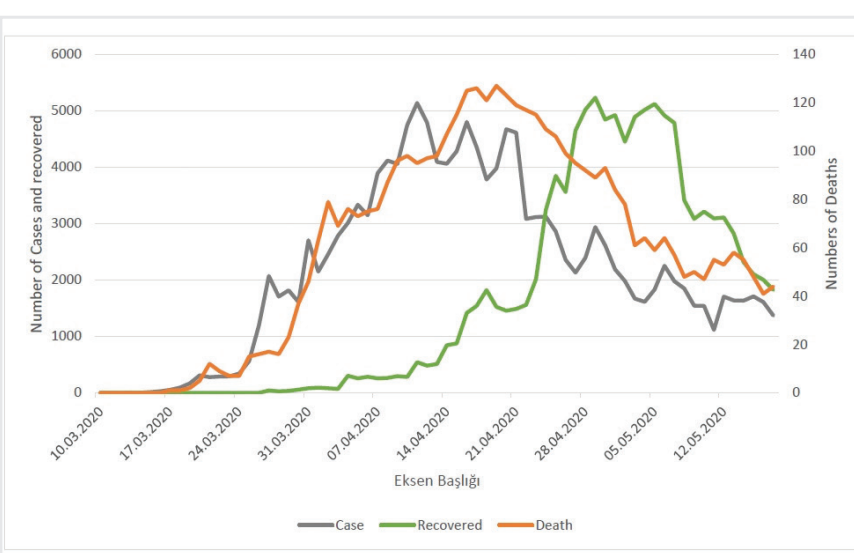

Figure 1. COViD-19 distribution of daily case, death and recovery numbers 


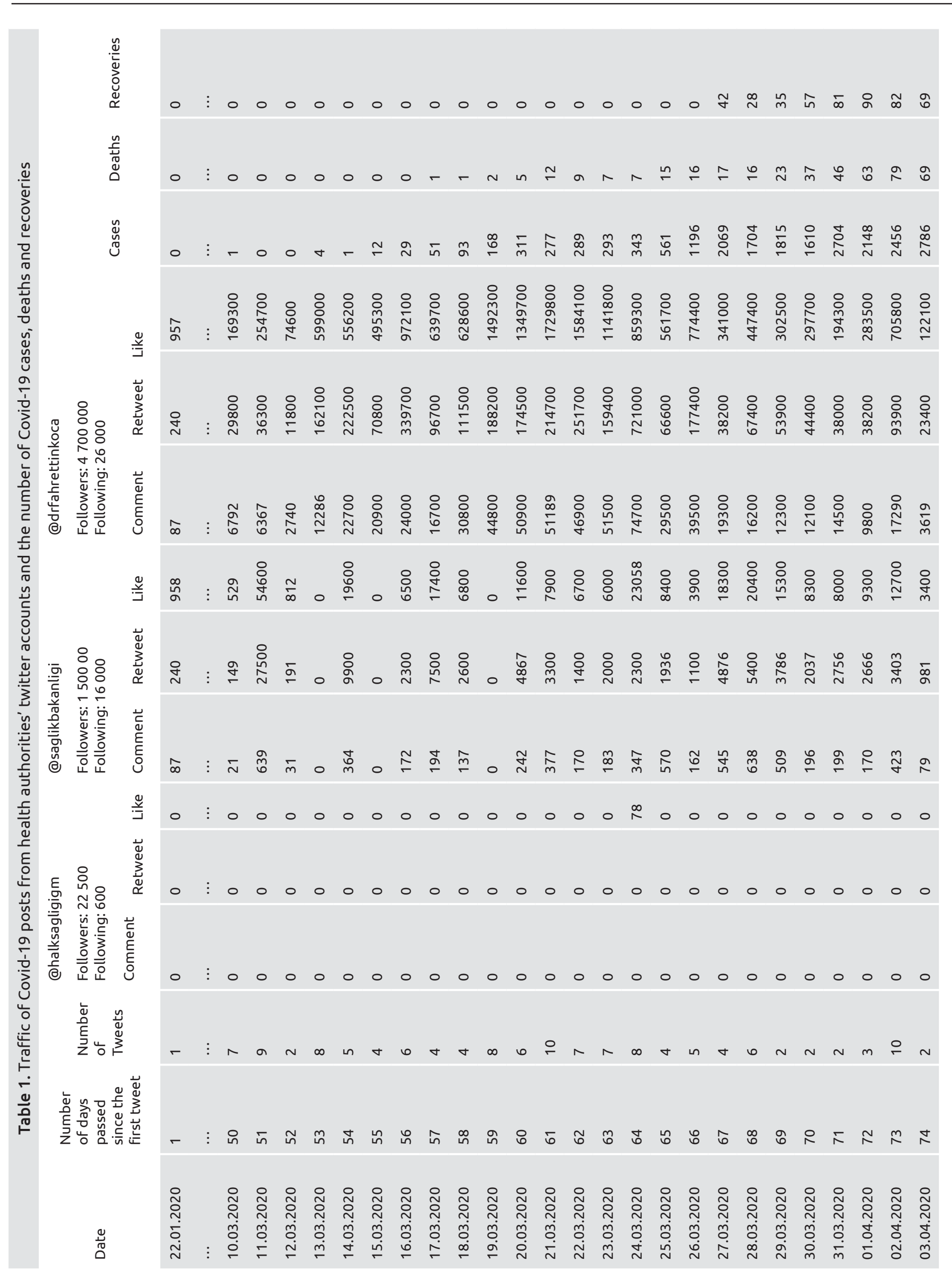




$$
\begin{aligned}
& \text { 命 } \\
& \text { ำกำ }
\end{aligned}
$$

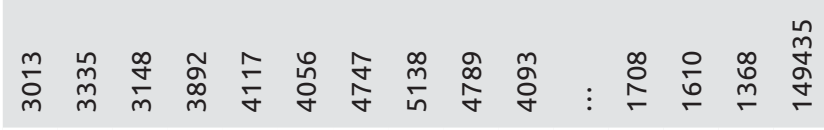

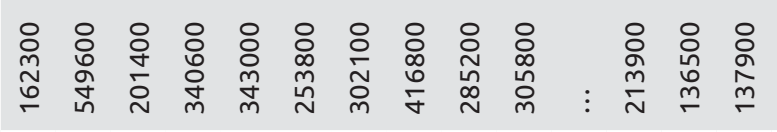

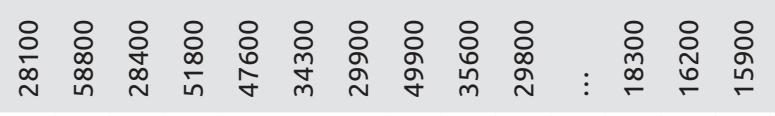

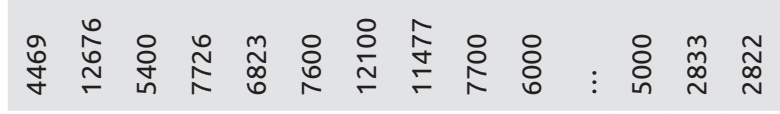

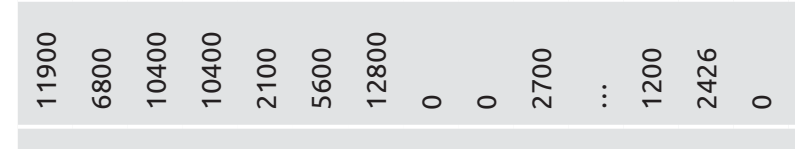

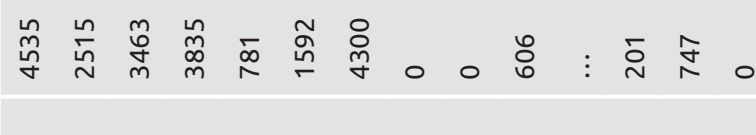

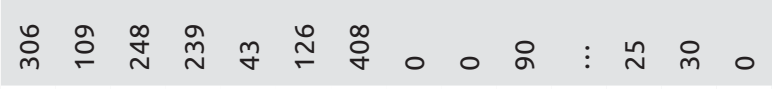$$
00000000000 \text { in }
$$

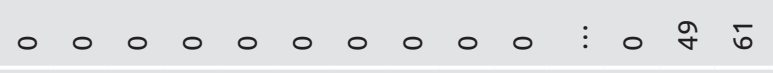$$
000000000000001000
$$$$
\text { in } m m \text { in in } m m \text { in } m \sim \vdots m b m
$$

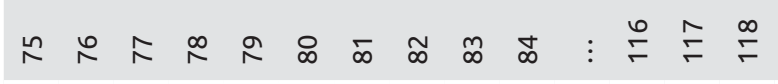

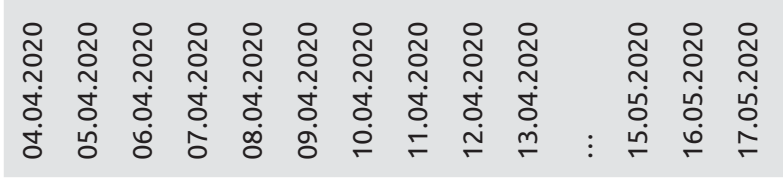

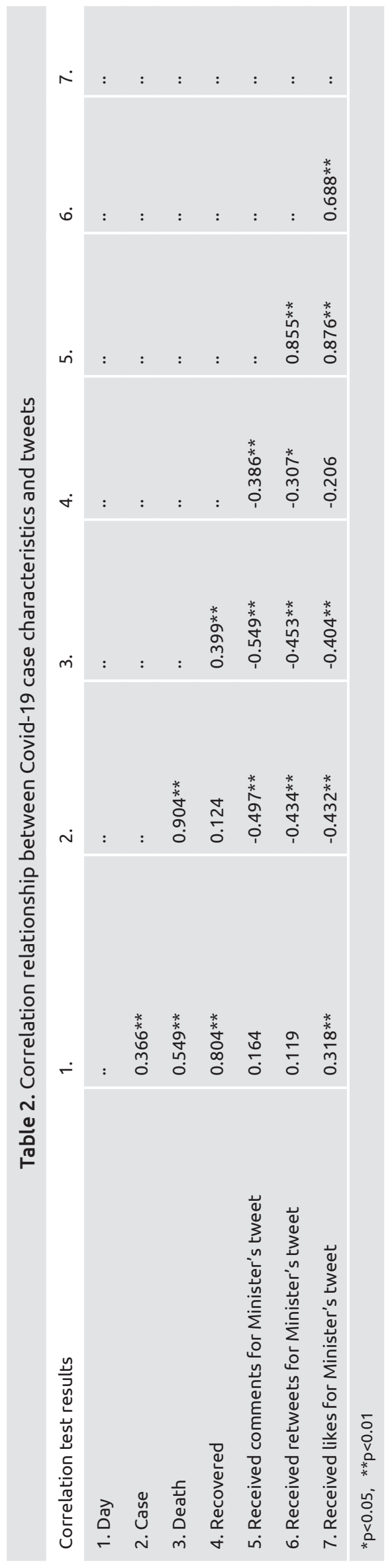


that comes into play in disaster situations. In this study, both the website established for COVID-19 and the twitter accounts of the health authorities were examined in order to evaluate risk communication through COVID-19 because interactive social media platforms can deliver an enormous amount of voluntary content when used properly (5).

In a study evaluating the national pandemic influenza plans of 28 European Union member countries, one of the themes with the highest score is risk communication (12). In the same direction, with the risk communication included in the Pandemic Influenza National Preparation Plan published in 2019 in Turkey, it started a preventive or mitigating preparatory work against future epidemic threats. The ways in which people can be reached and what kind of messages can be given during a pandemic are outlined in it. In line with the plan, a website was established by the Ministry of Health for COVID-19, which started in China and turned into a pandemic. It has been determined that there were a lot of written and visual materials for the public and healthcare personnel for COVID-19 and that this information is constantly updated. However, it has been determined that there was no written and visual material about children and pets.

As in natural disasters (7), social media can be useful in public administration during pandemics. Citizens can be directed to take necessary measures by being warned about the characteristics of a disaster and things to do (6). At this point, emergency managers use various platforms today in order to reach the public. One of these platforms is twitter which includes the features of user ID, timestamp, text, coordinates and retweet. In this social platform, comment, retweet and like interactions made specific to tweets also ensure that the same content is delivered to the followers of the interacting account. In this regard, it has been observed that the Turkish health authorities started to inform the public before COVID-19 became a global problem through twitter accounts. The health authorities regularly share messages to inform the public about COVID-19 every day. However, the first case in Turkey was seen on the $50^{\text {th }}$ day after the first tweet. A positive correlation was found between the number of cases, recoveries and deaths with each passing day, and the traffic of the Minister's tweets. The increase in tweet traffic with the passage of days indicates that it is important for health authorities to use their twitter accounts to reach the public directly and to inform them. For this reason, it can be said that social media platforms are one of the various mass media apparatuses that can be used to inform the public directly in the cases of threats and dangers.

The number of COVID-19 cases, deaths and recoveries also has a positive correlation in itself. However, although there was a middle correlation between the number of cases and deaths and the Minister's tweets, a negative low correlation was found between the number of recovery cases and the tweets of the Minister. The negative correlation between the number of recovery cases and the tweet traffic can be attributed to the lack of data since the data on recoveries appeared in later days.

\section{Study Limitations}

This study has several limitations. Firstly, due to the descriptive ecological design of the study, the cause-effect relationship should be interpreted carefully. Secondly, the hit rate of the website and the amount of time spent on the website are not known. Thirdly, there are no data about the number of people who saw these accounts but did not interact with the Twitter accounts of the health authorities. In addition, according to the We Are Social 2020 report, there are 62 million (74\%) internet users and 11.8 million (18\%) twitter users in Turkey which has a population of 84 million (13). Fourthly, although COVID-19 arrived late in Turkey thanks to the measures taken and the authorities attempted to prevent its spread across the country, the detected cases may not reflect the actual number.

\section{Conclusion}

It was found that the twitter accounts of the health authorities shared posts for protection from the COVID-19 pandemic even before it started to appear in Turkey. Among these accounts, a positive correlation was found between the tweet traffic of the Minister of Health and the COVID-19 cases, deaths and days. In addition, written and visual materials containing various information about COVID-19 were presented on a website by the Ministry of Health. Social platforms can be important risk communication tools in terms of informing and managing the public during disasters like pandemics. The utility of such platforms and the determination of the factors affecting them can be better demonstrated by various simulation models that can be made in the future.

\section{Ethics}

Peer-review: Externally and internally peer reviewed.

\section{Authorship Contributions}

Concept: M.N.K., H.K., C.Ç., K.K., Design: M.N.K., H.K., C.Ç., K.K., Data Collection or Processing: M.N.K., H.K., C.Ç., K.K., Analysis or Interpretation: M.N.K., H.K., C.Ç., K.K., Literature Search: M.N.K., H.K., C.Ç., K.K., Writing: M.N.K., H.K., C.Ç., K.K.

Conflict of Interest: No conflict of interest was declared by the authors.

Financial Disclosure: The authors declared that this study received no financial support.

\section{References}

1. Past Pandemics | Pandemic Influenza (Flu) | CDC [Internet]. Last Accessed Date:23.03.2020. Available from: https://www.cdc.gov/flu/ pandemic-resources/basics/past-pandemics.html

2. Veil SR, Littlefield RS, Rowan KE. Dissemination as success: Local emergency management communication practices. Public Relat Rev [Internet]. 2009;35:449-51. Available from: http://linkinghub. elsevier.com/retrieve/pii/S0363811109000897 
3. T.C.Health Ministry. National preparedness plan for pandemic influenza [Internet]. Ankara; 2019. Available from: https://www.grip. gov.tr/depo/saglik-calisanlari/ulusal_pandemi_plani.pdf

4. Kayman H, Ablorh-Odjidja A. Revisiting Public Health Preparedness: Incorporating Social Justice Principles Into Pandemic Preparedness Planning for Influenza Harvey. J Public Heal Manag Pract [Internet].2006;12:373-80. Available from: http://content.wkhealth.com/linkback/openurl?sid=WKPTLP: landingpage\&an=00124784-200607000-00011

5. Steiger E, de Albuquerque JP, Zipf A. An advanced systematic literature review on spatiotemporal analyses of twitter data. Trans GIS 2015;19:809-34. Available from: http://doi.wiley.com/10.1111/ tgis. 12132

6. Latonero M, Shklovski I. Emergency management, twitter, and social media Evangelism. Int J Inf Syst Cris Response Manag 2011;3:116. Available from: http://services.igi-global.com/resolvedoi/resolve. aspx?doi $=10.4018 /$ jiscrm.2011100101

7. Wang Z, YeX. Social media analytics for natural disaster management. Int J Geogr Inf Sci 2018 ;32:49-72. Available from: https://doi.org/ $10.1080 / 13658816.2017 .1367003$

8. Muniz-Rodriguez K, Ofori SK, Bayliss LC, Schwind JS, Diallo $\mathrm{K}$, Liu M, et al. Social Media Use in Emergency Response to
Natural Disasters: A Systematic Review With a Public Health Perspective. Disaster Med Public Health Prep 2020;14:139-49. Available from: https://www.cambridge.org/core/product/identifier/ S1935789320000038/type/journal_article

9. The Lancet. COVID-19: fighting panic with information. Lancet [Internet]. 2020;39:537. Available from: http://dx.doi.org/10.1016/ S0140-6736(20)30379-2

10. Leung GM, Leung K. Crowdsourcing data to mitigate epidemics. Lancet Digit Heal 2020;2:e156-7. Available from: http://dx.doi.org /10.1016/S2589-7500(20)30055-8

11. WHO. Coronavirus disease 2019 [Internet]. Last Accessed Dare: 30.03.2020. Available from: https://www.who.int/emergencies/ diseases/novel-coronavirus-2019

12. Droogers M, Ciotti M, Kreidl P, Melidou A, Penttinen P, Sellwood C, et al. European Pandemic Influenza Preparedness Planning: A Review of National Plans, July 2016. Disaster Med Public Health Prep 2019;13:582-92. Available from: https://www.cambridge.org/ core/product/identifier/S1935789318000605/type/journal_article

13. Digital 2020 - We Are Social Last Accessed Date: 30.03.2020. Available from: https://wearesocial.com/digital-2020 